\title{
Data averaging challenge
}

\author{
Juris Meija ${ }^{1}$
}

Accepted: 21 October 2021 / Published online: 4 January 2022

(c) Crown copyright in right of Canada 2022

We would like to invite you to participate in the Analytical Challenge, a series of puzzles to entertain and challenge our readers. This special feature of "Analytical and Bioanalytical Chemistry" has established itself as a truly unique quiz series, with a new scientific puzzle published every three months. Readers can access the complete collection of published problems with their solutions on the ABC homepage at http://www.springer.com/ abc. Test your knowledge and tease your wits in diverse areas of analytical and bioanalytical chemistry by viewing this collection.

In the present challenge, average is the topic. And please note that there is a prize to be won (a Springer book of your choice up to a value of $€ 100$,- given to one winner selected randomly). Please read on...

\section{Meet the challenge}

Scientists make use of averages all the time to summarize the results, often without giving much thought to them. Not that long ago, in 1755, Thomas Simpson, Professor of Mathematics at the Royal Academy at Woolwich, outlined the advantages of averaging observations. Simpson noted that "taking the mean of several observations, has not been so generally received, but that some persons, of considerable note, have been of opinion, and even publicly maintained, that one single observation taken with due care, was as much to be relied on as the mean of a greater number" [1].

But there are so many kinds of averages! Geometric mean, for example, is used to find the optimum isotope ratio in isotope dilution analyses [2] or to summarize bioassay

Published in the topical collection celebrating ABCs 20th Anniversary.

Juris Meija

juris.meija@nrc-cnrc.gc.ca

1 National Research Council Canada, Ottawa, ON K1A 0R6, Canada

data [3] and harmonic mean is used to evaluate the overall rate of simultaneous reactions [4], just to name a few. A more general problem, as Churchill Eisenhart noted in his 1971 Presidential address to the American Statistical Association, is "what mean should be taken when the measurements are not all equally good" [5]?

\section{The challenge}

The topic of this Challenge is to "average" the results! We shall consider the atomic weight determinations of tellurium. This was one of the elements that Mendeleev had most problems when developing his Periodic System, because he just didn't like the value of its atomic weight. From 1882, Frank W. Clarke produced comprehensive evaluations of the atomic weights, and we shall use data from his 1897 edition, which was the last Mendeleev would see in his lifetime. By the turn of the twentieth century, there were six good measurements available for the atomic weight of tellurium, each using a different method of gravimetric analysis [6] and these are summarized in Table 1.

What value and uncertainty would you assign to the atomic weight of tellurium from these data?

Table 1 Summary of atomic weight determinations of tellurium from Clarke's 1897 edition of Recalculation of the atomic weights $(\mathrm{H}=1$ scale $)$

\begin{tabular}{lll}
\hline Method & Result & $\begin{array}{l}\text { Standard } \\
\text { uncertainty }\end{array}$ \\
\hline 1 & 127.040 & 0.024 \\
2 & 126.303 & 0.036 \\
3 & 126.209 & 0.020 \\
4 & 126.650 & 0.045 \\
5 & 126.502 & 0.212 \\
6 & 125.960 & 0.233 \\
\hline
\end{tabular}




\section{Declarations}

Conflict of interest The author declares no competing interests.

\section{References}

1. Simpson T. A letter to the Right Honourable George Earl of Macclesfield, President of the Royal Society, on the advantage of taking the mean of a number of observations, in practical Astronomy. Philos Trans R Soc. 1755;49:82-93. https://doi.org/10.1098/rstl. 1755.0020.

2. Riepe W, Kaiser H. Massenspektrometrische Spurenanalyse von Calcium, Strontium und Barium in Natriumazid durch Isotopenverdünnungstechnik. Z Anal Chem. 1966;223:321-35. https://doi. org/10.1007/BF00513462.

3. <1033> Biological assay validation. USP 40-NF 35. US Pharmacopeial Convention.

4. Martinez MN, Bartholomew MJ. What does it "mean"? A review of interpreting and calculating different types of means and standard deviations. Pharmaceutics. 2017;9:14. https://doi.org/10.3390/ pharmaceutics9020014.
5. Eisenhart C. The development of the concept of the best mean of a set of measurements from antiquity to the present day. 131st Annual Meeting of the American Statistical Association, Colorado State University, Ft Collins CO, 24 Aug 1971. https://www. york.ac.uk/depts/maths/histstat/eisenhart.pdf

6. Clarke FW. A recalculation of the atomic weights. Washington DC: Smithsonian Institution. 1897. https://archive.org/details/ recalculationofa00clarrich

We invite our readers to participate in the Analytical Challenge by solving the puzzle above. Please send the correct solution to abc@ springer.com by April 1, 2022. Make sure you enter "Data averaging challenge" in the subject line of your e-mail. The winner will be notified by e-mail and their name will be published on the "Analytical and Bioanalytical Chemistry" homepage at http://www.springer.com/ $\mathrm{abc}$ and in the journal (volume 414/issue 16) where readers will find the solution and a short explanation.

The next Analytical Challenge will be published in 414/9, April 2022. If you have enjoyed solving this Analytical Challenge, you are invited to try the previous puzzles on the ABC homepage.

Publisher's note Springer Nature remains neutral with regard to jurisdictional claims in published maps and institutional affiliations. 